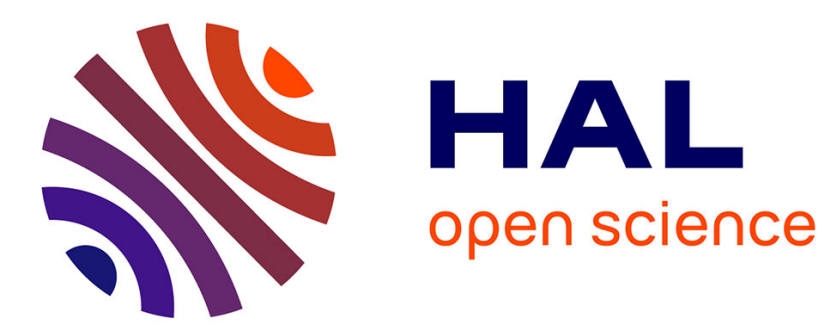

\title{
How do firms agglomerate? A study of FDI in france
} Matthieu Crozet, Thierry Mayer, Jean-Louis Mucchielli

\section{To cite this version:}

Matthieu Crozet, Thierry Mayer, Jean-Louis Mucchielli. How do firms agglomerate? A study of FDI in france. Regional Science and Urban Economics, 2004, 34, pp.27-54. 10.1016/S0166-0462(03)00010-3 . hal-01019657

\section{HAL Id: hal-01019657 \\ https://hal-sciencespo.archives-ouvertes.fr/hal-01019657}

Submitted on 7 Jul 2014

HAL is a multi-disciplinary open access archive for the deposit and dissemination of scientific research documents, whether they are published or not. The documents may come from teaching and research institutions in France or abroad, or from public or private research centers.
L'archive ouverte pluridisciplinaire HAL, est destinée au dépôt et à la diffusion de documents scientifiques de niveau recherche, publiés ou non, émanant des établissements d'enseignement et de recherche français ou étrangers, des laboratoires publics ou privés. 


\title{
How do firms agglomerate? A study of FDI in France
}

\author{
Matthieu Crozet $^{\mathrm{a}}$, Thierry Mayer ${ }^{\mathrm{b}, *}$, Jean-Louis Mucchielli ${ }^{\mathrm{a}}$

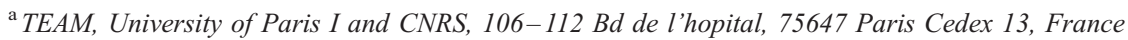 \\ ${ }^{\mathrm{b}}$ University of Paris I (TEAM), CERAS, CEPII and CEPR, 9 rue Georges Pitard, 75015 Paris, France
}

Received 25 April 2000; received in revised form 12 August 2002; accepted 27 December 2002

\begin{abstract}
This paper studies the determinants of location choice by foreign investors in France using a sample of almost 4000 foreign investments over 10 years and 92 locations. Concerning agglomeration effects, we find very strong evidence of positive spillovers between firms, and identify detailed patterns of clustering, assessing, for instance, the countries of origin and the industries for which those spillovers are the most substantial. Concerning regional policies, we find very little evidence of any positive impact. Finally, we identify a 'learning process' of FDI, the location decisions becoming more remote from the country of origin during the period we study. (C) 2003 Elsevier B.V. All rights reserved.
\end{abstract}

\section{Introduction}

Regional policies are largely used by local, national or European authorities in order to try and influence the location of economic activity in favor of lagging regions. Public authorities are particularly anxious to attract foreign investors, often thought to be a source of productivity increases by local firms in addition to creating new jobs. Related to these practices is the now well-documented finding that firms cluster in space (see Henderson and Kuncoro, 1996; Devereux and Griffith, 1998; Mayer and Mucchielli,

* Corresponding author. Tel.: +33-1-4407-8267.

E-mail addresses: crozet@univ-paris1.fr (M. Crozet), tmayer@univ-paris1.fr (T. Mayer), jlmuc@univ-paris1.fr (J.-L. Mucchielli). 
1999; Head et al., 1995, 1999, for recent results on that topic using a similar methodology as that used here). The decision makers implementing promotion and regional policies often have the idea in mind that being successful in attracting a first critical set of firms will generate a virtuous mechanism of self-reinforcing agglomeration of firms in the territory targeted.

This paper analyzes location choices of foreign investors in France. It is particularly focused on the measurement of agglomeration effects - the positive influence of a firm's location choice on the probability that the subsequent firms make the same choice-and the identification of the effect of regional policies used by public authorities to attract firms.

The existing empirical literature on agglomeration effects has mainly consisted of national-level studies (Wheeler and Mody, 1992; Devereux and Griffith, 1998) or choices of states in the USA (Carlton, 1983; Friedman et al., 1992; Head et al., 1995, 1999). The preceding work on location choices in Europe at a lower geographical level than countries has considered choices of regions by foreign investors in the European territory (Ferrer, 1998). Mayer and Mucchielli (1999) considered, in an integrated way, the national and regional choices of Japanese investors in Europe. Some papers have considered location problems at a very thin geographical level for Brazil (Hansen, 1987), China (Head and Ries, 1996) and Indonesia (Henderson and Kuncoro, 1996). However, to our knowledge, nobody has studied the determinants of location choice at a very detailed level for a European country that would be a major receiver of FDI (see, however, Guimarães et al., 2000, for a very thin analysis of location choice of FDI within Portugal). This paper is the first to consider individual firms' decisions for over 90 territorial units in France.

One of our objectives is to study in more detail the characteristics of agglomeration effects. Due to a very large dataset, we are notably able to differentiate the determinants of location depending on the country of origin of the investor and the industry of the plant located in France. Our results give insights for the following questions that are likely to be important for the policy maker: Does the nationality of the firms matter for agglomeration effects? Do firms cluster more with other firms from the same country? Do firms show a preference for regions within France that are near to their home market? Do all industries exhibit the same pattern of geographic concentration? We show that the nationality of the investor is important in location patterns. There are certain countries sharing a border with France for which investors show a very strong tendency to locate near their country of origin. However, this tendency is declining over time, which suggests some learning process with respect to the difficulty of operating a plant abroad. We also observe very different behavior depending on the industry. With respect to agglomeration effects, it is shown that firms cluster with their competitors, but that this behavior depends on the nationality of both the competitors and the investor.

We then analyze the effect of both French and European regional policies on location choice. We show that foreign investors are, to a large extent, not sensitive to investment incentives. Even when regional policies appear to have a statistically significant positive effect, the magnitude of this effect is very low compared to other determinants.

The remainder of the paper is as follows. Section 2 presents the theoretical determinants of location choice using a very simple oligopolistic competition model that yields an 
estimable equation for the location choice of firms. Section 3 describes the econometric model and the data used. Section 4 presents results on general and industry level location patterns, focusing on agglomeration effects. Section 5 presents results on the impact of regional policies and Section 6 concludes.

\section{Theoretical foundations}

Location choice determinants can be broadly classified into four large groups: demand that can be expected on the chosen location, factor costs that would be faced, the number of 'local' and foreign firms active in that same location and public policies designed to attract firms.

The sign expected on the two first variables is very widely accepted to be respectively positive and negative. The influence of the number of firms is more complicated and results from a trade-off between agglomeration and dispersion forces. On the one hand, a long strand of papers in location theory insists on the fact that geographic distance isolates firms from competition. A rise in the number of firms in a given location shifts prices down in that location and therefore reduces incentives to locate there. On the other hand, positive externalities between firms can emerge from technological spillovers or other mechanisms recently celebrated by the economic geography literature (Krugman, 1991; Venables, 1996). The relative strengths of the two forces shape the extent of geographical clustering of firms.

Investment promotion policies can take various forms: job creation subsidy, temporary exemption from local taxes, low levels of corporate taxation, etc. Everything else equal, firms should be positively influenced by this determinant in their choice.

All these determinants can be synthesized in a very simple formal framework, yielding an estimable equation describing the profitability of choosing a particular location. Suppose firms use quantity as their strategic variable and let demand take a generalized Cobb-Douglas form where price and income elasticities can differ from 1:

$$
Q=\frac{\alpha m^{\gamma}}{p^{\beta}}
$$

where $\alpha$ is the share of income spent on the particular good considered, $m$ is the income (exogenous here) of consumers, $\beta$ is price elasticity and $\gamma$ income elasticity, and $Q$ is total quantity demanded at price $p$, this demand being satisfied by locally producing firms. ${ }^{1}$ Suppose that firms have identical production costs when producing in the same location, ensuring the individual quantities will be equal in equilibrium: $Q=N q, N$ being the number of active firms on the market. The after-tax profit of a representative firm willing to produce and sell at this location is $\pi=(1-t)$

\footnotetext{
1 This assumption is, of course, not realistic as firms in each location usually serve consumers in several locations. It is, however, only made for analytical clarity and our demand variable will take into account the fact that firms serve several locations.
} 
$(p-c) q$, where $t$ is the corporate tax rate (representing promotion policies in a large sense) and $c$ is a unit production cost function.

Using (1) and adding first-order conditions over the $N$ firms, we obtain the following expression for total equilibrium quantity:

$$
Q=N q=\frac{\alpha m^{\gamma}}{N^{\beta}}\left[\frac{N \beta-1}{c \beta}\right]^{\beta},
$$

which gives equilibrium price $p=[N \beta /(N \beta-1)] c$. Substituting $q$ and $p$ in the profit function, we obtain the following expression:

$$
\pi=(1-t)\left[\frac{\alpha m^{\gamma}}{N^{(\beta+1)}}\left(\frac{\beta}{N \beta-1} c\right)^{1-\beta}\right] .
$$

Supposing that price elasticity is superior to $1(\beta>1)$, profit is a decreasing function of corporate tax rate, production costs and number of active firms, that is competition intensity (a traditional effect in location theory; see d'Aspremont et al., 1979). Profit is also an increasing function of consumers' expenditure, i.e. of market size.

Let us specify a bit more the unit cost function such that unit cost is a function of ongoing wage $(w)$ and includes a positive externality related to the number of firms: ${ }^{2}$

$$
c=w^{\theta_{w}} N^{-\theta_{N}}, \theta_{w}>0, \theta_{N}>0 .
$$

The influence of the number of firms is then ambiguous. With a sufficiently large number of firms, the profit function can be approximated by

$$
\pi=(1-t) \alpha m^{\gamma}\left(w^{\theta_{w}}\right)^{1-\beta} N^{\left[\theta_{N}(\beta-1)-2\right]} .
$$

Eq. (2) is log-linear and gives us the theoretical foundations of our empirical estimation of location determinants. The signs of the first three variables are still clearly determined, but the sign of the count of firms variable now depends on the importance of the externality parameter relative to the negative impact of competition.

\section{Implementation of the location choice model}

\subsection{The econometric model}

\subsubsection{Conditional logit}

The economic decision studied in theoretical location models is by nature a discrete choice among several alternatives made by individual firms. Turning to empirical

2 This externality takes a form comparable to that specified by Belleflamme et al. (2000). For the foundations of such externalities and distinctions between different possible types of externalities, the reader can consult the seminal work of Marshall (1920), recently inspiring a large number of papers, including Krugman (1991), David and Rosenbloom (1990), Arthur (1990, 1994), and Fujita and Thisse (1996, 2002). 
matters, the econometric model should therefore ideally have these features too. For this reason, models with a qualitative endogenous variable and particularly conditional logit models have been widely used in the preceding empirical work on industrial location.

This model assumes that firms maximize a profit function subject to uncertainty when choosing a location. The deterministic component of the profit function consists of the various attributes of locations that can influence the profitability of building a plant in a particular location (Eq. (2)). The random component consists of maximization errors, unobserved characteristics of choices or measurement errors. While the real underlying profit yielded by alternative locations cannot be observed, what is observed is the actual choice of each firm and the characteristics of the alternative locations.

There is a set $I=(1, \ldots, i, \ldots n)$ of possible location sites and the location $i$ offers a profit $\pi_{i}(a)$ to an investor locating affiliate $a$.

There are two types of determinants of location. In order to capture the attractiveness of location $i$ to the representative investor (common to all investors, independent of time of entry, the industry or the country of origin of the affiliate), we first introduce a fixed effect for each location, denoted $\theta_{i}$. Second, there is a set of variables $\mathbf{U}_{i}(a)=\left[\ln X_{i 1}(a), \ldots\right.$, $\left.\ln X_{i k}(a)\right]$, with $\mathbf{X}_{i}(a)=\left[X_{i 1}(a), \ldots, X_{i k}(a)\right]$ representing observable characteristics of location $i$ that vary across investors, since investors differ in the date of location chosen, industry and country of origin.

The resulting profit equation yielded by location $i$ to affiliate $a$ is then

$$
\pi_{i}(a)=\theta_{i}+\mathbf{B U}_{i}(a)+\epsilon_{i}(a),
$$

where $\mathbf{B}$ is the vector of unknown coefficients to be estimated and $\epsilon_{i}(a)$ is the unobservable advantage of location $i$ for affiliate $a$. It is assumed that an investor chooses location $i$ if it yields higher profits than any other possible choice. The probability of choosing $i$ is thus

$$
\operatorname{Prob}\left[\pi_{j}(a)<\pi_{i}(a)\right]=\operatorname{Prob}\left[\boldsymbol{\epsilon}_{j}(a)<\boldsymbol{\epsilon}_{i}(a)+\theta_{i}-\theta_{j}+\mathbf{B U}_{i}(a)-\mathbf{B U}_{j}(a)\right] \forall j \neq i .
$$

Under a type I extreme value distribution of the error term, this probability of choosing location $i$ (denoted $P_{i}(a)$ ) is known to take the following form (McFadden, 1984):

$$
P_{i}(a)=\frac{\mathrm{e}^{\theta_{i}+\mathbf{B U}_{i}(a)}}{\sum_{j=1}^{n} \mathrm{e}^{\theta_{j}+\mathbf{B} \mathbf{U}_{j}(a)}} .
$$

Using this formula for the probability of investing in each location, the coefficient on each variable is then estimated by maximum likelihood. The expected signs and magnitudes of those coefficients are dictated by Eq. (2).

We follow our theoretical model and take all variables in logs. As a consequence, all coefficients can roughly be interpreted as elasticities for an 'average' investor of the change of each variable in a location on the probability of investing in that location. Indeed, it can be easily shown, using (3), that

$$
\frac{A P_{i}(a)}{A X_{i 1}(a)} \frac{X_{i 1}(a)}{P_{i}(a)}=b_{1}\left(1-P_{i}(a)\right) \text {, }
$$


where $b_{1}$ is the coefficient estimated on variable $X_{1}$. In our sample, the average probability across investors of choosing a location $i$ will be around 0.1 . The coefficient on each variable is therefore a slight overestimate of the elasticity of location choice probability with respect to a change in this variable from its average value across the sample. We will also be interested in calculating the marginal effect of a change in a variable (particularly for count of firms variables), which is

$$
\frac{A P_{i}(a)}{A X_{i 1}(a)}=b_{1}\left(1-P_{i}(a)\right) \frac{P_{i}(a)}{X_{i 1}(a)}
$$

\subsubsection{Nested logit}

The assumed distribution of the error term in the construction of the logit model ensures a property of this model called the Independence of Irrelevant Alternatives (IIA). It can be immediately seen from (3) that the ratio of probabilities of choosing two locations is independent of the characteristics of any third location. Put differently, the choices should all be equally substitutable to the investor. This assumption, however, has some chance of being violated in our case, as we think that some départements will be closer substitutes than others. A possible solution to this issue, adopted in papers by Hansen (1987), Devereux and Griffith (1998) and Mayer and Mucchielli (1999), is to nest location choices into a multiple-level tree structure in order to take into account the fact that some départements have a higher level of substitution than others.

This nested logit specification (see Maddala, 1983, for a detailed description of this model) involves three steps.

- First, specifying a tree structure, we propose two 'natural' structures here. We adopt the French administrative grouping of the 92 départements into 21 regions (respectively NUTS 3 and NUTS 2 levels of the Eurostat classification); this specification will be labelled Nest 1. We also try to look at a very important distinction in France between the Ile-de-France region, ${ }^{3}$ on the one hand, and the rest of France on the other; this specification will be labelled Nest 2.

- The second step involves logit estimation of location choices at the lower level of the tree (choice of département), restricting the alternative choices to be within each defined nest.

- In a third step, the consistency of the assumed tree structure must be checked through a logit estimation of location choice at the upper level of the tree (choice of region).

Stated formally, assume that, within the whole set $I=(1 \ldots, i, \ldots n)$ of possible location sites, there are two (disjoint) sets of départements belonging respectively to regions $\mathscr{I}$ and $\mathscr{J}$. Suppose that département $i$ belongs to region $\mathscr{I}$, and let us denote with subscript $i \mathscr{I}$ the variables that vary across départements and regions and, with

\footnotetext{
3 Regrouping Paris and its suburbs (and representing 29.3\% of French GDP in 1995 against 2.2\% of French area).
} 
subscript $\mathscr{I}$, the variables that do not vary inside region $\mathscr{I}$. The profit function can be restated as

$$
\pi_{i \mathscr{I}}(a)=\theta_{i \mathscr{I}}+\theta_{\mathscr{I}}+\mathbf{C} \mathbf{U}_{i \mathscr{I}}(a)+\mathbf{D} \mathbf{U}_{\mathscr{I}}(a)+\boldsymbol{\epsilon}_{i \mathscr{I}}(a) .
$$

The probability of choosing location $i$ is now the product of choosing first $\mathscr{I}$ and then $i$ inside $\mathscr{I}$, that is $P_{i \mathscr{I}}(a)=P_{i \mid \mathscr{I}}(a) P_{\mathscr{I}}(a)$, with

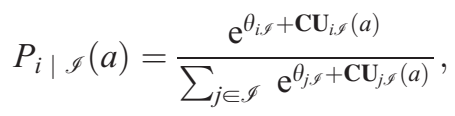

and

$$
P_{\mathscr{I}}(a)=\frac{\mathrm{e}^{\theta_{\mathscr{I}}+\mathbf{D} \mathbf{U}_{\mathscr{I}}(a)+\sigma \mathrm{IV}_{\mathscr{I}}}}{\mathrm{e}^{\theta_{\mathscr{I}}+\mathbf{D} \mathbf{U}_{\mathscr{I}}(a)+\sigma \mathrm{IV}_{\mathscr{I}}}+\mathrm{e}^{\theta_{\mathscr{f}}+\mathbf{D} \mathbf{U}_{\mathscr{f}}(a)+\sigma \mathrm{IV}_{\mathscr{f}}}}
$$

where $\mathrm{IV}_{\mathscr{I}}=\ln \left(\sum_{j \in \mathscr{I}} \mathrm{e}^{\theta_{j \mathscr{G}}+\mathbf{C U}_{j \mathscr{G}}(a)}\right)$ is called the inclusive value. The coefficient $\sigma$ is of particular interest, since, if it takes a value of 1 , the nested logit collapses to the standard conditional logit model without a tree structure. If it is estimated to be 0 , the départements are estimated to be near perfect substitutes inside the region and only the region choice matters. The tree structure is thus considered to have some relevance for the investor when the inclusive value coefficient is significantly estimated to be between 0 and 1 .

\subsection{The data}

\subsubsection{The dependent variable}

We consider location decisions by foreign investors in France. The left-hand side variable needed is the location choice of each investor over all the 92 French départements ${ }^{4}$ with its nationality, date of investment and industry. The main database (IEF) comes from the Direction du Trésor and was constructed based on the (now softened) legal obligation for foreign firms to ask for an administrative authorization to invest in France. This database reports much information on foreign affiliates operating in France, including date and town of investment, employment, the different shareholders, their nationality and respective shares, etc. We use the 1996 version of the database and consider investments from 1985 to 1995 , mainly because of data limitations on the right-hand side variables. We only consider firms for which the industry reported is manufacturing. We sum up the shares of foreign investors by country of origin and then keep only the firms for which the largest share is held by a foreign country and for which this share is at least $10 \%$. We attribute the firm to the first country of ownership when several countries have shares in a given firm.

The main problem of this database is that only the location of the headquarters is reported. However, using the identification number of the firm, it is possible to track the producing units belonging to the firm and then obtain its precise location using a different database made available by the Ministry of Industry. The procedure was, therefore, the

\footnotetext{
4 Which correspond to the NUTS 3 level in the Eurostat geographical classification of regions for France.
} 
following. Take all investments with their dates in IEF and keep all producing units that belonged to a firm in IEF and were 'born' the same year or after the date reported in IEF. The date of creation of the plant is inferred by looking at the first year where that establishment was reported by the French Ministry of industry. This gives us our sample of location choices, which consists of a close to exhaustive list of producing units owned by foreign companies in France and established during that period. The sample contains 3902 observations over 206 industries.

\subsubsection{Demand variable}

Unlike most of the empirical literature on location choice, ${ }^{5}$ the demand variable taken here is not local GDP. The French départements are of relatively small size and it seems clear that foreign investors target consumers far beyond the frontier of the département they choose to locate in. However, transport costs make distant consumers more difficult to reach and we must take this difficulty of access into account. We do so by using a variable inspired by the concept of market potential introduced by Harris (1954):

$$
\operatorname{MARK}_{i}=\mathrm{GDP}_{i}+\sum_{j \neq i}\left(\frac{\mathrm{GDP}_{j}}{d_{i j}}\right) .
$$

Our demand variable, labeled MARK, therefore takes into account the local GDP of the chosen location and adds the GDPs of all other locations weighted by their distance to the chosen location.

The source of the GDP data is REGIO, the Eurostat regional database that allocates French GDP between French départements. The distance variable consists of real road distances (fastest trip between the respective centers of the two départements) that were collected using an electronic road atlas. MARK is, of course, only a proxy for the real demand perceived by firms.

Hanson (1998) provides an empirical estimation of a theory-based market potential which is a highly non-linear function requiring industry level estimates of transport costs, local demand, local prices (wages) and elasticities of substitution. It is very difficult here to obtain data that could allow for more sophisticated demand variables at this geographical level. However, we believe that our proxy is reasonable for a large proportion of the industries in the sample and the results seem to confirm this belief.

\subsubsection{Labour costs variable}

We were able to calculate an industry-level wage per capita variable for each département and year of our sample. Using data on producing units operating in each département, ${ }^{6}$ we include the average wage per capita of the industry, département and year

\footnotetext{
5 A notable exception being Friedman et al. (1992), who use a demand variable similar to that used here in their analysis of foreign investment in the United States.

6 When data were missing because the département had no firm in the four-digit industry, we used an average of the average national wage for this industry and the average wage across industries in this location.
} 
relevant for the investment considered. The variable is labeled $\mathrm{W}$ and is calculated as the total wage bill paid in the industry divided by employment in this industry. Note that, in this calculation, we keep only producing establishments of the considered industry, département and year combination.

\subsubsection{Agglomeration variables}

The agglomeration variables consist of cumulated counts of firms based on that sample. The calculation follows Head et al. (1995) and consists of the count of firms belonging to the same industry (but not belonging to the same parent company) that were located in each département a year before the considered investment.

We introduce here new dimensions in the measurement of agglomeration effects. We first try to identify the 'nationality' of the agglomerative force. We try to answer the following question: Does a firm exhibit the same tendency to cluster with other firms from the same country of origin, other non-French firms and/or French firms? There will therefore be three agglomeration variables: NH, NO and NF accounting, respectively, for the effect of the presence of same home country firms, other foreign firms and French firms. The sign and magnitude of each coefficient on those variables depend on the relative strengths of the competition effect and positive externalities exposed in the theory section. A comparison of coefficients on those variables will enable us to draw insights into the possibly different effects depending on different nationalities of the investors.

Three precisions need to be made here in terms of interpretation. First, note that we follow Head et al. (1995) and assume a specification of those agglomeration effects that is linear in logs, of the form $\mathrm{NH}^{e} \mathrm{NO}^{f} \mathrm{NF}^{g}$, where $e, f$ and $g$ are (very close to) the respective elasticities of the probability of choosing a département (see Section 3.1). We have a particular interest in assessing whether the elasticities of those variables are the same $(e=f=g)$ in that specification.

Second, we are able, due to the large size of the sample, to differentiate between country of origin and industry in the location behavior of multinational firms. This is, of course, of primary importance for policy issues as it will appear that there is a large amount of heterogeneity, calling for different measures by public authorities if they intend to attract FDI and conduct regional policies.

Third, agglomeration variables are constructed in a way to take into account neighboring location sites. It is very likely that competition forces and/or agglomeration benefits that we try to capture with those covariates span over administrative borders of départements. Head et al. (1995) try to account for this by adding counts of firms from neighboring states. We prefer to remain consistent with our approach on demand and specify the three variables as distance-weighted counts of firms: ${ }^{7}$

$$
\mathrm{NH}_{i}=\text { Home firms count }_{i}+\sum_{j \neq i}\left(\frac{\text { Home firms count }}{j}\right)+1,
$$

\footnotetext{
7 We add one to all these variables as in Head et al. (1995) because, at the detailed industry level, we consider that there are numerous cases where counts of firms are zero, specially for $\mathrm{NH}$.
} 


$$
\begin{aligned}
& \mathrm{NO}_{i}=\text { Other foreign firms count } \\
& i
\end{aligned}
$$

\subsubsection{Distance to home country variable}

As shown below, the location choices of FDI are also influenced by proximity to the investor's home market. We take into account this tendency of foreign firms to invest in locations near their country through a distance variable labeled DIS. It is calculated as the great circle distance between the capital city of the investing firm's country of origin and the capital city of each département available as a location. We chose, however, to take Chicago for the USA, Toronto for Canada and Frankfurt for Germany, although, in this work, the precise location of the city chosen does not really impact significantly on the relative distances to each département.

\subsubsection{Grants variables}

The main instrument of regional policy available to the French government is called the Prime d'Aménagement du Territoire (PAT) and consists of labor-related grants for creating or maintaining jobs in lagging regions. Both French and foreign investments are eligible for these grants and about half the annual funding goes to foreign investors. We estimate the influence of this policy instrument on location choice by introducing a variable called PAT, which takes into account the funds granted to each region for the year of the considered investment.

Some French regions are also eligible for the European Commission regional policy involving grants that are sometimes used to attract FDI, but most of the time consists of attempts to improve the economic environment with an expected indirect effect on attractiveness.

In the time period we consider, there were three main types of funds which the Commission granted to French regions: Objective 2, Objective 5b, and 'community initiatives' funds. ${ }^{8}$ Objective 2 aims at promoting the conversion of areas affected by industrial decline. Objective $5 \mathrm{~b}$ is aimed at rural areas affected by problems linked to the decline of agriculture. ${ }^{9}$ There are numerous French regions receiving grants under those two objectives, the two main receivers being Nord-Pas-de-Calais and Lorraine. We also include the 'community initiatives' funds. ${ }^{10}$ The corresponding variables are the grants

\footnotetext{
8 There were no funds given under Objective 1 (granted to regions with GDP per head below $75 \%$ of the Union average) in our sample.

9 These funds are targeted towards "vulnerable rural areas" and are used in order to promote "Diversification of activities, product quality, rural tourism ... training schemes with the key aim of creating employment". They do not incorporate subsidies to agricultural production and are totally separated from the Common Agricultural Policy measures.

10 These are four special programmes, currently absorbing 5.35\% of the budget of the Structural Funds: Interreg III (promotes cross-border, transnational and interregional cooperation), Urban II (supports "innovative strategies to regenerate cities and declining urban areas"), Leader+ ("new local strategies for sustainable development"), and Equal ("seeks to eliminate the factors leading to inequalities and discrimination in the labour market").
} 
given to each region under each relevant objective, respectively: OBJ2, OBJ5B and HOBJ. $^{11}$

The data made publicly available by the European Commission is surprisingly scarce. However, we were able to gather data on grants by Objective and region in France for the years 1989, 1990 and 1991, which were the years when FDI was at its peak in France. We can therefore estimate the influence of those grants on the location decisions of foreign investors for those three years because the number of observations remains substantial. The PAT grants were not much easier to collect and we are able to assess their influence over the years 1985, 1986, 1987, 1991 and 1994. Note that all data on grants is available at the NUTS 2 level, that is at a more aggregated geographical level than the level at which we observe location choices (NUTS 3).

\section{Results}

\subsection{Spatial patterns of investment}

Figs. 1 and 2 show the spatial distribution of foreign affiliates in France for investors originating from other European countries. The size of the circles represents the number of investments received by the département (all affiliates in the département being attributed to the central city for this graph).

It is readily apparent that the region around Paris has been a major recipient of investments for FDI from all origin countries. It is also striking that some investors have a preference for locations in France that are near the border with their origin country. This is particularly apparent for FDI originating from Belgium, The Netherlands, Germany and Switzerland. Similarities in culture, language, tastes, distribution networks, etc. might therefore be an important determinant of location choices by investors originating from a country that has a common border with France. This behavior is to be compared with other econometric relationships uncovered in international trade and FDI studies exhibiting a positive impact of cultural similarity on goods or factor flows. Concerning trade flows, for instance, it is well known that a common language constitutes a powerful motivation for bilateral trade. Furthermore, it has recently been reported by Rauch (1999) and Rose (2000), for instance, that colonial ties have a strong positive effect on trade. Rauch (2001) surveys several papers, finding a positive impact on bilateral trade of migrants from the partner country.

Our interpretation of this pattern is that regions in France that share a border with the country of origin of the investor offer important advantages in the trade-off between the costs of operating abroad and access to French consumers: whereas those locations might not offer ideal access to the remaining French consumers, they present a whole set of features that are common with the country of origin of the investor and can therefore reduce the cost of operating abroad.

\footnotetext{
11 More details on these funds and the European Union regional policy goals and instruments in general can be found at http://europa.eu.int/comm/regional_policy/index_en.htm.
} 

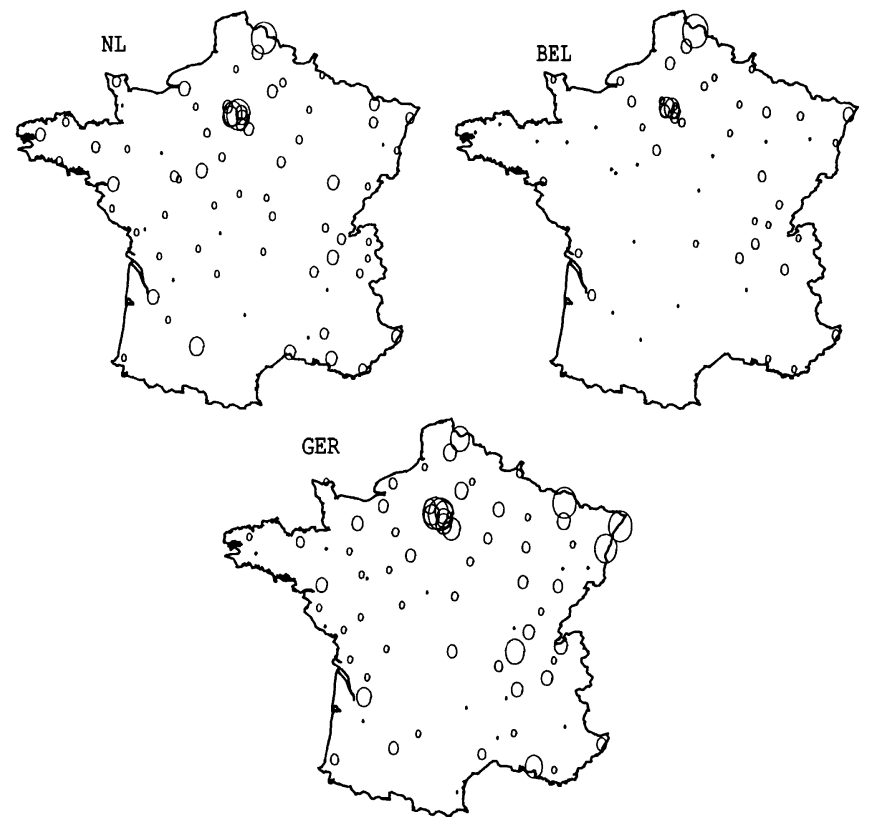

Fig. 1. Patterns of foreign affiliates in France: FDI from Belgium, Germany and the Netherlands.
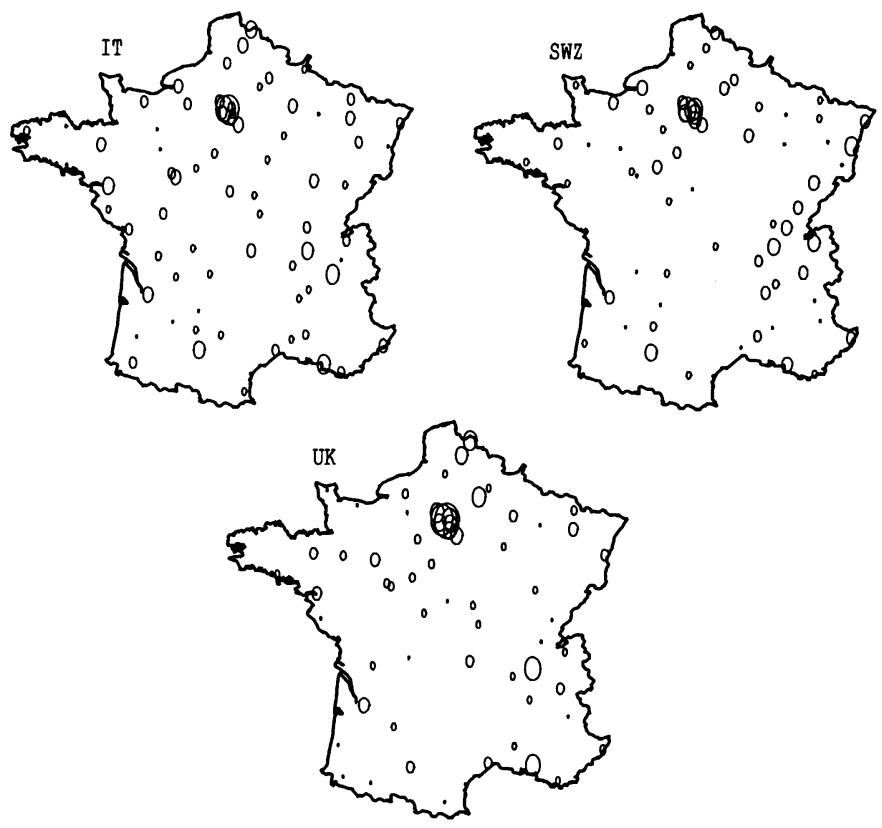

Fig. 2. Patterns of foreign affiliates in France: FDI from Italy, Switzerland and the United Kingdom. 


\subsection{Econometric results}

Table 1 reports results using four different specifications on the complete sample of investments. The first column gives coefficients of a standard conditional logit estimation, which gives a benchmark to which various specifications will be compared. The second column reports estimates from a fixed effects (NUTS 3 dummy variables) conditional logit. The last two columns report coefficients from nested logit estimations where the upper level choice is NUTS 2 regions (Nest 1) and Ile-de-France versus the rest of France (Nest 2). For these two estimations, coefficients on the inclusive values are reported at the bottom of the table.

Results in the first column show, as expected, a positive influence of the market potential and a negative influence of wages. We also obtain a positive effect of the presence of competitors. This shows that agglomeration forces dominate dispersion forces on average, this finding being an indicator of spillovers that might exist between firms. It is noteworthy that the coefficient on agglomeration with French firms is much higher than agglomeration with other foreign firms, either of the same or a different country of origin. This might indicate that the competition faced by a foreign investor in France is fiercer with other foreign firms than with French firms. This might also be a sign that the technological spillovers passing through informal communications or the inter-firm mobility of qualified workers is substantially easier with French firms.

Table 1

Choice of location of foreign investors in France

\begin{tabular}{|c|c|c|c|c|}
\hline \multirow[b]{2}{*}{$\begin{array}{l}\text { Model: } \\
\text { Fixed effect: }\end{array}$} & \multicolumn{4}{|c|}{ Dependent variable: chosen département } \\
\hline & No & NUTS 3 & $\begin{array}{l}\text { Nest } 1 \\
\text { NUTS } 3\end{array}$ & $\begin{array}{l}\text { Nest } 2 \\
\text { NUTS } 3\end{array}$ \\
\hline $\begin{array}{l}\text { Ln proximity of same } \\
\text { home country firms }(\ln \mathrm{NH})\end{array}$ & $\begin{array}{l}0.22 * * * \\
(0.06)\end{array}$ & $\begin{array}{l}0.27 * * * \\
(0.06)\end{array}$ & $\begin{array}{c}0.11 \\
(0.09)\end{array}$ & $\begin{array}{l}0.21 * * * \\
(0.08)\end{array}$ \\
\hline $\begin{array}{l}\text { Ln proximity of other } \\
\text { foreign firms }(\ln \mathrm{NO})\end{array}$ & $\begin{array}{l}0.35^{* * *} \\
(0.04)\end{array}$ & $\begin{array}{l}0.47 * * * \\
(0.04)\end{array}$ & $\begin{array}{l}0.54 * * * \\
(0.05)\end{array}$ & $\begin{array}{l}0.52 * * * \\
(0.04)\end{array}$ \\
\hline $\begin{array}{l}\text { Ln proximity of French } \\
\text { firms }(\ln N F)\end{array}$ & $\begin{array}{l}0.89 * * * \\
(0.03)\end{array}$ & $\begin{array}{l}1.03 * * * \\
(0.03)\end{array}$ & $\begin{array}{l}1.29 * * * \\
(0.04)\end{array}$ & $\begin{array}{l}1.25 * * * \\
(0.03)\end{array}$ \\
\hline $\begin{array}{l}\text { Ln market } \\
\text { potential (ln MARK) }\end{array}$ & $\begin{array}{l}0.35^{* * *} \\
(0.03)\end{array}$ & $\begin{array}{l}2.83 * * * \\
(0.69)\end{array}$ & $\begin{array}{l}2.31^{* *} \\
(1.16)\end{array}$ & $\begin{array}{l}1.79 * * \\
(0.84)\end{array}$ \\
\hline Ln wage $(\ln W)$ & $\begin{array}{l}-0.43^{* * *} \\
(0.09)\end{array}$ & $\begin{array}{r}-0.16 \\
(0.10)\end{array}$ & $\begin{array}{r}-0.18 \\
(0.12)\end{array}$ & $\begin{array}{r}-0.07 \\
(0.11)\end{array}$ \\
\hline $\begin{array}{l}\text { Ln distance to } \\
\text { home country (ln DIS) }\end{array}$ & $\begin{array}{c}-0.75^{* * *} \\
(0.05) \\
3902\end{array}$ & $\begin{array}{c}-0.78 * * * \\
(0.06) \\
3902\end{array}$ & $\begin{array}{c}-1.67 * * * \\
(0.34) \\
3902\end{array}$ & $\begin{array}{c}-0.74 * * * \\
(0.06) \\
3902\end{array}$ \\
\hline $\begin{array}{l}\text { No. obs. } \\
\text { Pseudo- } R^{2}\end{array}$ & 0.164 & 0.185 & 0.241 & 0.173 \\
\hline $\begin{array}{l}\text { Fixed effect } \\
\text { Inclusive value }\end{array}$ & & & $\begin{array}{c}\text { NUTS } 2 \\
0.56^{* * *} \\
(0.02)\end{array}$ & $\begin{array}{c}\text { Ile de France } \\
0.34^{* * *} \\
(0.03)\end{array}$ \\
\hline Pseudo- $R^{2}$ & & & 0.199 & 0.128 \\
\hline
\end{tabular}

Note: standard errors in parentheses with significance at the $* * * 1 \%, * * 5 \%$ and $* 10 \%$ level. 
Another interpretation of this result can be made in terms of informational externalities (see Banerjee, 1992; De Coster and Strange, 1993, for theoretical models). Suppose that French firms have better information than foreign companies on the 'true' comparitive attractiveness of French départements. The location of French firms would therefore convey more information than the location of foreign affiliates for a prospective investor. As a consequence, foreign investors would be more willing to replicate French firms' choices than choices made by other multinational companies, which might have information no better than theirs.

Informational externalities of that kind, where foreign firms 'learn' through proximity with French firms, might also result from labor market spillovers, i.e. from information transmitted by hired local workers who previously worked for French competitors.

As highlighted in Section 3.1, the coefficients on these variables are slight overestimates of the elasticity of the probability of a location being chosen with respect to the agglomeration variables. The exact formula of this elasticity for a given affiliate $a$ is $b\left(1-P_{i}(a)\right)$, where $b$ is the estimated coefficient. In our sample, the average probability of a location being chosen is $\bar{P}=0.092$.

However, a $10 \%$ increase in $\mathrm{NH}$ is very different from a $10 \%$ increase in NF, because there are many more French firms, on average, than foreign firms in each département/industry/year combination. Adding one more foreign firm will very often result in a $100 \%$ increase in $\mathrm{NH}$, while adding one more French firm will, most of the time, be associated with a very low percentage increase in $\mathrm{NF}^{12}$ It is therefore also interesting to look at the effect of a unitary increase in each of those variable on the probability of attracting the next investments. For a change in $\mathrm{NH}$, for instance, this is given for the average investor by $b_{\mathrm{NH}}(1-\bar{P})(\bar{P} / \overline{\mathrm{NH}})$. The resulting figures for those marginal effects are 0.018 for $\mathrm{NH}, 0.020$ for $\mathrm{NO}$ and 0.014 for NF. A unitary increase in French firms' agglomeration variable therefore has a lower impact on the probability of future location choices than the same increase in the number of foreign firms. The message yielded by these elasticities and marginal effects on agglomeration effects is the following. While foreign investors predominantly follow the location patterns of local (French) firms, hosting one additional foreign firm yields more benefit to subsequent attractiveness than hosting one more French firm. Local authorities competing for investments or regional policies trying to promote spatial equity in FDI location patterns should therefore target FDI in order to achieve their goals. Whether those authorities have instruments that can actually influence location choices of first foreign investors in order to trigger cumulative agglomeration of FDI is a different issue that will be investigated in Section 5.

The fixed effect regression in column 2 is mainly characterized by a very important increase of the coefficient on market potential and a very large decrease in the coefficient

12 Recall that our agglomeration variables in $i$ are $1+$ local count of firms in $i+$ remote count of firms weighted by distance to $i$. Therefore, a unitary increase in $\mathrm{NH}_{i}$, for instance, can be interpreted as a new investment in $i$ or as an increase in investments in neighboring départements that yield the same overall rise in $\mathrm{NH}_{i}$ once discounted by bilateral distance. 
on wages, which becomes insignificant. An increases in market potential over time therefore seems to be much more important for attractiveness than differences in perceived demand across départements. On the contrary, it appears that the time-invariant component of wage differences across French regions is far more important than a wage increase over time. $^{13}$

With respect to nested logit estimations, both tree structures have coefficients on inclusive values that are highly significant and within the $0-1$ range, which indicates that the tree structure is indeed relevant. The Nest 1 specification, however, seems to offer a higher overall fit in both estimation steps. Here again, the market potential effect is much higher than in the benchmark estimation, which means that, inside a NUTS 2 region, investors are very sensitive to choosing the highest demand département, whereas this is less apparent when choices are considered independently of the chosen NUTS 2 region. An important result emerging from the nested specification is that the wage variable loses significance. This is apparent in both nests, but especially true for the Nest 2 specification, suggesting that the main explanation for the negative coefficient in the column 1 benchmark specification is the very large gap between wages in Ile-de-France and elsewhere in France (in 1990, for instance, our wage variable was, on average, 30\% higher in Ile-de-France than in the rest of the country). Another important result appearing in Nest 1 is that the coefficient on NH decreases and becomes insignificant, indicating that, inside each NUTS 2 region, the agglomeration behavior with respect to firms from the same country of origin is much less powerful. On the contrary, the coefficient on local firms (NF) is substantially increased, suggesting an important role for local agglomeration economies.

We now proceed to the estimation of location choice determinants of foreign investors in France by country of origin. We present in Table 2 the results for three different pooled regressions where certain coefficients are allowed to differ across countries of origin. We focus on the eight main countries investing in France, that is the United States $(21.3 \%$ of total location choices), Germany $(16.2 \%)$, the Netherlands $(12.5 \%)$, Italy $(10.8 \%)$, the United Kingdom (10.4\%), Switzerland (9.4\%), Belgium (6.4\%), and Japan (2.1\%). Regressions are run without fixed effects, and with NUTS 2 and NUTS 3 fixed effects in the three estimations. Three variables are interacted with country of origin dummy variables: agglomeration with same home country competitors, market potential and wages.

The results show substantial variability depending on the country of origin of the firm. Some countries, such as Italy and the Netherlands, show very low agglomeration effects compared to the rest of the sample and are less driven towards high market potential areas than the others. These two countries, as Belgium, are also much more sensitive to the level of labor costs in their location choices, these results being largely robust to alternative fixed effects specifications. The American investors seem to search out very productive workers despite their higher cost, as shown by the positive coefficient on wages.

13 Note that this pattern is common to other comparable location choice studies. Devereux and Griffith (1998) and Head et al. (1999) also conduct conditional logit estimations with fixed effects and find insignificant or even positive coefficients on wages. Both papers attribute those results to the attraction of foreign investors towards locations endowed with highly skilled workers, a feature that might also be valid here. 
Table 2

Location choice of foreign investors in France by country

\begin{tabular}{|c|c|c|c|c|c|c|}
\hline Fixed effect & No & & NUTS 2 & & NUTS 3 & \\
\hline \multicolumn{6}{|l|}{ Ln proximity of other } & $(0.04)$ \\
\hline \multicolumn{7}{|l|}{ Ln proximity of French } \\
\hline \multicolumn{7}{|c|}{ Ln proximity of same home country firms $(\ln N H)$} \\
\hline Belgium & $0.70 * *$ & $(0.27)$ & $0.66 * *$ & $(0.27)$ & $0.56^{* *}$ & $(0.28)$ \\
\hline Netherlands & $-0.81 * * *$ & $(0.25)$ & $-0.82 * * *$ & $(0.25)$ & $-0.58 * *$ & $(0.26)$ \\
\hline Germany & -0.01 & $(0.14)$ & -0.09 & $(0.14)$ & 0.03 & $(0.14)$ \\
\hline Italy & $-0.50^{*}$ & $(0.30)$ & -0.44 & $(0.30)$ & -0.08 & $(0.31)$ \\
\hline UK & $0.56 * * *$ & $(0.21)$ & $0.57 * * *$ & $(0.21)$ & $0.67 * * *$ & $(0.20)$ \\
\hline USA & 0.13 & $(0.11)$ & $0.23 * *$ & $(0.10)$ & $0.21 * *$ & $(0.11)$ \\
\hline Japan & $1.51 * *$ & $(0.67)$ & $1.63 * *$ & $(0.67)$ & $1.50 * *$ & $(0.66)$ \\
\hline Switzerland & 0.12 & $(0.17)$ & 0.18 & $(0.17)$ & 0.10 & $(0.17)$ \\
\hline Other countries & $0.91 * *$ & $(0.43)$ & $0.80 *$ & $(0.42)$ & 0.63 & $(0.42)$ \\
\hline \multicolumn{7}{|c|}{ Ln market potential (In MARK) } \\
\hline Belgium & $0.54 * * *$ & $(0.10)$ & $0.63 * * *$ & $(0.10)$ & $2.77 * * *$ & $(0.70)$ \\
\hline Netherlands & 0.04 & $(0.08)$ & 0.12 & $(0.08)$ & $2.15 * * *$ & $(0.70)$ \\
\hline Germany & $0.28 * * *$ & $(0.06)$ & $0.38 * * *$ & $(0.07)$ & $2.44 * * *$ & $(0.70)$ \\
\hline Italy & -0.11 & $(0.07)$ & -0.02 & $(0.08)$ & $2.01 * * *$ & $(0.70)$ \\
\hline UK & $0.41 * * *$ & $(0.08)$ & $0.50 * * *$ & $(0.09)$ & $2.64 * * *$ & $(0.70)$ \\
\hline USA & $0.24 * * *$ & $(0.06)$ & $0.32 * * *$ & $(0.06)$ & $2.40 * * *$ & $(0.70)$ \\
\hline Japan & $0.71 * * *$ & $(0.16)$ & $0.82 * * *$ & $(0.16)$ & $3.04 * * *$ & $(0.72)$ \\
\hline Switzerland & $0.32 * * *$ & $(0.08)$ & $0.39 * * *$ & $(0.09)$ & $2.47 * * *$ & $(0.70)$ \\
\hline Other countries & $0.43 * * *$ & $(0.07)$ & $0.53 * * *$ & $(0.08)$ & $2.66 * * *$ & $(0.70)$ \\
\hline \multicolumn{7}{|l|}{ Ln Wage $(\ln W)$} \\
\hline Belgium & $-1.32 * * *$ & $(0.33)$ & $-1.18 * * *$ & $(0.34)$ & $-1.15^{* * *}$ & $(0.35)$ \\
\hline Netherlands & $-1.13 * * *$ & $(0.24)$ & $-1.02 * * *$ & $(0.25)$ & $-0.71 * * *$ & $(0.25)$ \\
\hline Germany & -0.15 & $(0.24)$ & 0.03 & $(0.25)$ & 0.08 & $(0.25)$ \\
\hline Italy & $-1.50 * * *$ & $(0.20)$ & $-1.51 * * *$ & $(0.21)$ & $-1.23 * * *$ & $(0.22)$ \\
\hline UK & -0.18 & $(0.30)$ & -0.03 & $(0.31)$ & 0.02 & $(0.31)$ \\
\hline USA & $0.76 * * *$ & $(0.20)$ & $0.88 * * *$ & $(0.20)$ & $0.90 * * *$ & $(0.20)$ \\
\hline Japan & -0.50 & $(0.60)$ & -0.29 & $(0.60)$ & -0.40 & $(0.58)$ \\
\hline Switzerland & 0.02 & $(0.32)$ & 0.25 & $(0.32)$ & 0.33 & $(0.33)$ \\
\hline Other countries & 0.24 & $(0.31)$ & 0.48 & $(0.31)$ & $0.53^{*}$ & $(0.31)$ \\
\hline $\begin{array}{l}\text { Ln distance to home } \\
\text { country (ln DIS) }\end{array}$ & $\begin{array}{l}-0.67 * * * \\
3902\end{array}$ & $(0.06)$ & $\begin{array}{l}-0.71 * * * \\
3902\end{array}$ & $(0.06)$ & $\begin{array}{l}-0.72 * * * \\
3902\end{array}$ & $(0.07)$ \\
\hline No. obs. & & & & & & \\
\hline Pseudo- $R^{2}$ & 0.175 & & 0.18 & & 0.194 & \\
\hline
\end{tabular}

Note: standard errors in parentheses with significance at the $* * * 1 \%, * * 5 \%$ and $* 10 \%$ level.

This very large dataset enables us to uncover important differences in firms' behavior in terms of clustering. While, on average, firms tend to follow the choices of competitors from the same country, there are large differences depending on the nationality of the 
investor. Belgian firms, for instance, tend to follow Belgian competitors approximately as strongly as firms from the Netherlands tend to avoid other firms from the Netherlands. This is one of the first studies where such heterogeneity, informative of the relative strength of competition and agglomeration effects, has been identified. It is also noteworthy that the coefficient on this variable, while it can be of either sign in theory, has never to our knowledge been reported as being significantly negative. Overall, the investors most sensitive to agglomeration effects are the Japanese, English, Belgian and American, while those most sensitive to dispersion forces are Dutch, Italian and, to a lesser extent, German.

\subsection{The learning process of foreign investment}

A possible explanation for the negative sign of distance from the origin country on location choice is that proximate départements share common characteristics with the origin country that make them particularly favorable sites for location. ${ }^{14}$ The reason why some investors show a preference for regions in France contiguous with their home market might be a trade-off between access to French consumers and ease of operation. The disadvantage faced by foreign affiliates with respect to local firms due to their poorer knowledge of the characteristics of the local market is one of the oldest ideas in the theory of FDI (see Hirsch, 1976, for instance). Let us consider the example of German FDI in France. It is likely that locations in France near the German border share sufficient common 'cultural' characteristics with Germany so that the cost of operating there (relative to local firms) is lower, ceteris paribus, than the cost of operating in more western locations in France.

The existence of transport costs, however, does not make those locations ideal basing points to serve the majority of French consumers. The trade-off could then work as follows. Suppose that firms gradually learn the characteristics of the French market once they have an affiliate anywhere in France. The first waves of German investment could then be concentrated near the German border in order to reduce the disadvantage of being a foreign affiliate. The next waves could gradually move west in order to improve access to consumers because firms have learned some of the characteristics of the market, thereby reducing their initial disadvantage.

Support for this intuition can be found by looking at the evolution of the coefficient on distance and market potential. We expect an increase in both, the first becoming less negative with time and the second more positive. If following your rivals also contributes to reducing your information gathering costs about the characteristics of the French market, we should then also expect a decrease in the coefficient on $\mathrm{NH}$.

Fig. 3 plots the three coefficients (and their respective 5\% confidence intervals) over the period of our sample and confirms the expected evolution for all three variables. ${ }^{15}$ The

14 One might also envision that this result reflects a relocation pattern of FDI: investors look for a location in France near their home market to enjoy relatively low production costs compared with those they face in their own country, without increasing the transport cost to their home market too much. While this explanation might be plausible for Swiss or German investors, it does not seem very likely for Belgian or Dutch ones.

15 In order to improve the stability and robustness of the estimations, we run logits for each couple of successive years $(1985-1986,1986-1987$, etc.). 


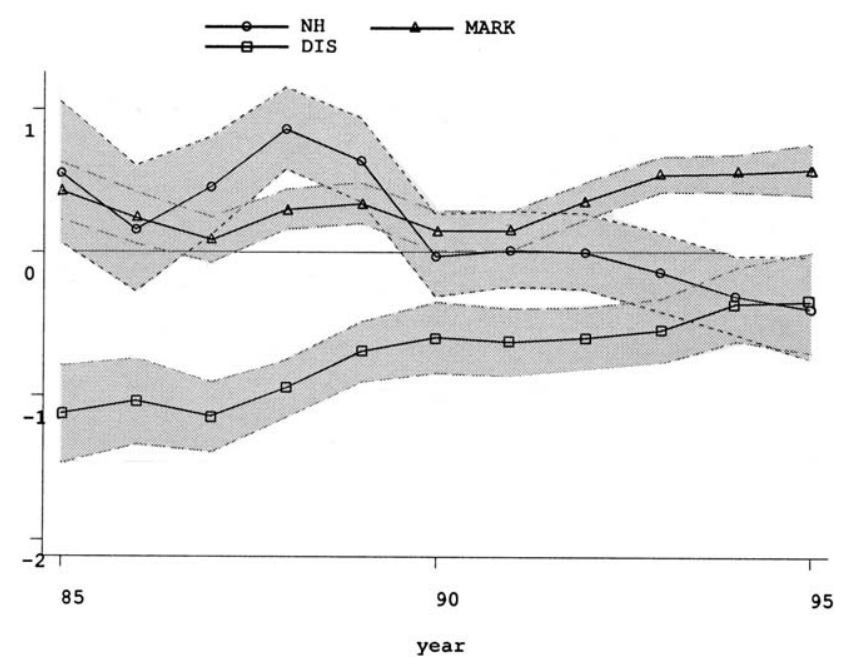

Fig. 3. Evolution of coefficients over time.

negative effect of distance is declining sharply over time, with a simultaneous increase of the coefficient on the market potential variable. The coefficient on distance starts at -1.09 and ends at -0.33 : in the beginning of the sample, reducing the distance from the country of origin by $50 \%$ increases the probability of receiving an investment by roughly $50 \%$, but by only about $15 \%$ at the end. We interpret this as evidence of some learning process of foreign investors, gradually moving from 'familiar' locations near the country of origin to more central locations in France, where access to consumers is better. It should also be noted that the coefficient on same country of origin competitors shifts from clustering behavior to avoiding behavior (the coefficient is significantly negative at the end of the period).

Table 3 gives regression results where the main variables of interest are interacted with time period dummies (one for years 1985 to 1990, the other for the period 1991 to 1995) in order to examine the evolution of coefficients over time, both in a standard conditional logit specification and in a fixed effects specification. Confirming expectations from the learning process hypothesis and the trends in Fig. 3, the distance coefficient is lower (in absolute value) in the second subperiod, and the coefficient on $\mathrm{NH}$ also decreases sharply. The rise in the market potential coefficient is less important, but the figure shows that this rise is most pronounced in the latest years, suggesting that expanding the dataset to more recent years might reveal a more important increasing trend.

\subsection{Results by industry}

We end this section by proceeding to regressions at the industry level to examine which industries exhibit the most significant agglomeration effects and thus potentially constitute the most interesting targets for promotion policies, as an initial advantage in the attraction of those industries could then result in self-reinforcing agglomeration in the départements making a good start. Due to the very large sample used we are able to conduct the analysis 
Table 3

Location choice of foreign investors: evolution of coefficients

\begin{tabular}{|c|c|c|}
\hline \multirow{2}{*}{$\begin{array}{l}\text { Model: } \\
\text { Fixed effect }\end{array}$} & \multicolumn{2}{|c|}{ Dep. var: chosen département } \\
\hline & No & NUTS 3 \\
\hline $\begin{array}{l}\text { Ln proximity of same home } \\
\text { country firms }(\ln \mathrm{NH})^{*}(85-90)\end{array}$ & $\begin{array}{l}0.62 * * * \\
(0.10)\end{array}$ & $\begin{array}{l}0.58 * * * \\
(0.10)\end{array}$ \\
\hline $\begin{array}{l}\text { Ln proximity of same home } \\
\text { country firms }(\ln N H)^{*}(91-95)\end{array}$ & $\begin{array}{l}-0.18^{* *} \\
(0.09)\end{array}$ & $\begin{array}{c}0.00 \\
(0.08)\end{array}$ \\
\hline $\begin{array}{l}\text { Ln proximity of other } \\
\text { foreign firms }(\ln \mathrm{NO}) *(85-90)\end{array}$ & $\begin{array}{l}0.28 * * * \\
(0.06)\end{array}$ & $\begin{array}{l}0.47 * * * \\
(0.06)\end{array}$ \\
\hline $\begin{array}{l}\text { Ln proximity of other } \\
\text { foreign firms }(\ln N O) *(90-95)\end{array}$ & $\begin{array}{l}0.43 * * * \\
(0.05)\end{array}$ & $\begin{array}{l}0.48 * * * \\
(0.05)\end{array}$ \\
\hline $\begin{array}{l}\text { Ln proximity of French } \\
\text { firms }(\ln N F)^{*}(85-90)\end{array}$ & $\begin{array}{l}0.88 * * * \\
(0.04)\end{array}$ & $\begin{array}{l}1.01 * * * \\
(0.04)\end{array}$ \\
\hline $\begin{array}{l}\text { Ln proximity of French } \\
\text { firms }(\ln N F) *(91-95)\end{array}$ & $\begin{array}{l}0.97 * * * \\
(0.04)\end{array}$ & $\begin{array}{l}1.06 * * * \\
(0.04)\end{array}$ \\
\hline $\begin{array}{l}\text { Ln market potential } \\
\qquad(\ln \text { MARK }) *(85-90)\end{array}$ & $\begin{array}{l}0.27 * * * \\
(0.05)\end{array}$ & $\begin{array}{l}1.74 * * \\
(0.74)\end{array}$ \\
\hline $\begin{array}{l}\text { Ln market potential } \\
(\ln \text { MARK })^{*}(91-95)\end{array}$ & $\begin{array}{l}0.41 * * * \\
(0.04)\end{array}$ & $\begin{array}{l}1.92 * * * \\
(0.72)\end{array}$ \\
\hline $\begin{array}{l}\text { Ln wage } \\
\qquad(\ln W)^{*}(85-90)\end{array}$ & $\begin{array}{c}-0.59 * * * \\
(0.14)\end{array}$ & $\begin{array}{l}-0.35^{* *} \\
(0.15)\end{array}$ \\
\hline $\begin{array}{l}\text { Ln wage } \\
\qquad(\ln W)^{*}(91-95)\end{array}$ & $\begin{array}{l}-0.25^{* *} \\
(0.13)\end{array}$ & $\begin{array}{r}-0.02 \\
(0.13)\end{array}$ \\
\hline $\begin{array}{l}\text { Ln distance to home } \\
\text { country (ln DIS)*(85-90) }\end{array}$ & $\begin{array}{c}-0.95 * * * \\
(0.07)\end{array}$ & $\begin{array}{l}-0.96 * * * \\
(0.08)\end{array}$ \\
\hline $\begin{array}{l}\text { Ln distance to home } \\
\text { country (ln DIS)*(91-95) }\end{array}$ & $\begin{array}{c}-0.53 * * * \\
(0.07)\end{array}$ & $\begin{array}{c}-0.61 * * * \\
(0.08)\end{array}$ \\
\hline $\begin{array}{l}\text { No. obs. } \\
\text { Pseudo- } R^{2}\end{array}$ & $\begin{array}{l}3902 \\
0.167\end{array}$ & $\begin{array}{l}3902 \\
0.186\end{array}$ \\
\hline
\end{tabular}

Note: standard errors in parentheses with significance at the $* * * 1 \%$ and $* * 5 \%$ level.

at the four-digit level, guaranteeing a very precise assessment of the industries that are more subject to agglomeration economies. Tables A.1 and A.2 in Appendix A rank industries using the average values of the three agglomeration variable coefficients. Table A.1 lists industries for which all three agglomeration variables have significant positive signs, and Table A.2 lists the other industries. There are 76 industries for which estimation of all variables is possible. Of these, eight have all three agglomeration variables significantly positive.

We see that industries often regarded as being characterized by strong positive spillovers appear in the first group of industries where we find very significant agglomeration effects. Computers are, of course, one of these, as is office machinery, for which the coefficients are extremely large. A $10 \%$ increase in the number of firms in a département roughly increasing the probability of investing there by $40 \%$ for this industry.

Another interesting result is the fact that, in the clothing industry, often referred to as being characteristic of a low-skill, labor-intensive industry, investors are very sensitive to wage differentials and much less to agglomeration economies. On the other hand, industries with significant agglomeration effects do not seem to be sensitive to the level of labor costs. 
We are therefore able to confirm differences in the location decisions of investors across industries that were previously largely hypothesized in the literature without being rigorously tested due to lack of data. We find, in particular, that industries that are often thought to be characterized by strong agglomeration economies more than labor cost considerations (such as computers, machine tools and car parts) indeed show this tendency. Conversely, low-skill industries such as clothing are not very sensitive to agglomeration economies, but seem to favor cost differentials. Also, industries that are closely spatially tied to final consumption such as magazines or newspapers show an overwhelming tendency to follow the spatial distribution of consumers rather than the spatial distribution of competitors.

\section{The influence of regional policies on location choice}

In this section, we estimate the influence of structural funds granted to French regions by the European Commission and of the main measure of French regional policy, the Prime d'Aménagement du Territoire (PAT). We first present several specifications of pooled regressions and then specific regressions by country of origin. Recall that, for all the regressions of this section, the number of observations is constrained by the availability of grants data. We consider location choices over 3 years for European structural funds and 5 years for the PAT.

\subsection{Pooled results}

Table 4 presents results for eight different specifications incorporating grant variables. The first four columns incorporate structural funds and the last four incorporate the PAT. ${ }^{16}$ For the two types of grant variables, we consider first a benchmark estimation without grant variables followed by a conditional logit estimation incorporating the grants and then two fixed effects estimations (one with NUTS 2 dummy variables and one with NUTS 3 dummy variables).

We see from columns 2 and 6 of the table that only community initiative grants and PAT coefficients are significantly positive. Furthermore, even for these grants, the size of the effect is smaller by an order of magnitude than for most other significant determinants. This means that, even in the few cases where some results of such policies are to be expected, they will be very largely outweighed by agglomeration or market potential considerations.

Our pooled results therefore leave little prospect for a major role of EU regional policies in reshaping the location patterns of FDI. Note first that we consider coordinated regional policy measures and not measures used unilaterally by individual regions to attract firms, such as tax cuts or subsidies. Our results are therefore not contradictory with papers by Devereux and Griffith (1998) and Head et al. (1999), for

\footnotetext{
16 We choose to present results separately for the two types of grants because there is only one year (1991) for which data are available for all grants. Regressions for this year (available upon request) show virtually no change in the coefficients on grants.
} 
Table 4

Influence of regional policies on location choice

\begin{tabular}{|c|c|c|c|c|c|c|c|c|}
\hline \multirow[b]{2}{*}{ Fixed effect: } & \multicolumn{4}{|c|}{ Dependent variable: chosen département } & \multirow[b]{2}{*}{ NUTS 3} & \multirow[b]{2}{*}{ No } & \multirow[b]{2}{*}{ NUTS 2} & \multirow[b]{2}{*}{ NUTS 3} \\
\hline & NUTS 3 & No & NUTS 2 & NUTS 3 & & & & \\
\hline $\begin{array}{l}\text { Ln proximity of same home } \\
\text { country firms }(\ln \mathrm{NH})\end{array}$ & $\begin{array}{l}0.34 * * * \\
(0.11)\end{array}$ & $\begin{array}{l}0.39 * * * \\
(0.11)\end{array}$ & $\begin{array}{l}0.39 * * * \\
(0.11)\end{array}$ & $\begin{array}{l}0.33 * * * \\
(0.11)\end{array}$ & $\begin{array}{l}0.21^{* *} \\
(0.10)\end{array}$ & $\begin{array}{l}0.21^{* *} \\
(0.10)\end{array}$ & $\begin{array}{l}0.21^{* *} \\
(0.10)\end{array}$ & $\begin{array}{l}0.21^{* *} \\
(0.10)\end{array}$ \\
\hline $\begin{array}{l}\text { Ln proximity of other } \\
\text { foreign firms }(\ln \mathrm{NO})\end{array}$ & $\begin{array}{l}0.55^{* * *} \\
(0.07)\end{array}$ & $\begin{array}{l}0.36 * * * \\
(0.07)\end{array}$ & $\begin{array}{l}0.37 * * * \\
(0.07)\end{array}$ & $\begin{array}{l}0.54 * * * \\
(0.07)\end{array}$ & $\begin{array}{l}0.47 * * * \\
(0.06)\end{array}$ & $\begin{array}{l}0.36^{* * *} \\
(0.06)\end{array}$ & $\begin{array}{l}0.36^{* * *} \\
(0.06)\end{array}$ & $\begin{array}{l}0.47 * * * \\
(0.06)\end{array}$ \\
\hline $\begin{array}{l}\text { Ln proximity of } \\
\text { French firms (ln NF) }\end{array}$ & $\begin{array}{l}1.06^{* * *} \\
(0.05)\end{array}$ & $\begin{array}{l}0.93 * * * \\
(0.05)\end{array}$ & $\begin{array}{l}0.94 * * * \\
(0.05)\end{array}$ & $\begin{array}{l}1.07 * * * \\
(0.05)\end{array}$ & $\begin{array}{l}1.05^{* * *} \\
(0.04)\end{array}$ & $\begin{array}{l}0.95 * * * \\
(0.04)\end{array}$ & $\begin{array}{l}0.97 * * * \\
(0.04)\end{array}$ & $\begin{array}{l}1.05^{* * *} \\
(0.04)\end{array}$ \\
\hline $\begin{array}{l}\text { Ln market } \\
\text { potential (ln MARK) }\end{array}$ & $\begin{array}{r}-1.66 \\
(2.67)\end{array}$ & $\begin{array}{l}0.34 * * * \\
(0.06)\end{array}$ & $\begin{array}{l}0.28 * * * \\
(0.08)\end{array}$ & $\begin{array}{r}-3.13 \\
(2.84)\end{array}$ & $\begin{array}{l}3.57 * * * \\
(0.91)\end{array}$ & $\begin{array}{l}0.40^{* * *} \\
(0.05)\end{array}$ & $\begin{array}{l}0.38^{* * *} \\
(0.06)\end{array}$ & $\begin{array}{l}3.62 * * * \\
(0.91)\end{array}$ \\
\hline Ln wage $(\ln W)$ & $\begin{array}{c}-0.39 * * \\
(0.18)\end{array}$ & $\begin{array}{l}-0.59 * * * \\
(0.16)\end{array}$ & $\begin{array}{l}-0.48^{* * *} \\
(0.17)\end{array}$ & $\begin{array}{c}-0.38^{* *} \\
(0.18)\end{array}$ & $\begin{array}{c}0.00 \\
(0.15)\end{array}$ & $\begin{array}{c}0.00 \\
(0.15)\end{array}$ & $\begin{array}{r}-0.06 \\
(0.15)\end{array}$ & $\begin{array}{c}0.00 \\
(0.15)\end{array}$ \\
\hline $\begin{array}{l}\text { Ln distance to home } \\
\text { country (ln DIS) }\end{array}$ & $\begin{array}{l}-0.80 * * * \\
(0.11)\end{array}$ & $\begin{array}{l}-0.79 * * * \\
(0.09)\end{array}$ & $\begin{array}{l}-0.77 * * * \\
(0.11)\end{array}$ & $\begin{array}{l}-0.81 * * * \\
(0.11)\end{array}$ & $\begin{array}{l}-0.75^{* * *} \\
(0.09)\end{array}$ & $\begin{array}{l}-0.74 * * * \\
(0.08)\end{array}$ & $\begin{array}{c}-0.74 * * * \\
(0.09)\end{array}$ & $\begin{array}{c}-0.75^{* * *} \\
(0.09)\end{array}$ \\
\hline $\begin{array}{l}\text { Ln objective } 2 \\
\text { grant }(\ln \mathrm{OBJ} 2)\end{array}$ & & $\begin{array}{c}0.00 \\
(0.01)\end{array}$ & $\begin{array}{c}-0.03 * * \\
(0.02)\end{array}$ & $\begin{array}{r}-0.03^{*} \\
(0.02)\end{array}$ & & & & \\
\hline $\begin{array}{l}\text { Ln objective } 5 b \\
\text { grant }(\ln \text { OBJ5b) }\end{array}$ & & $\begin{array}{c}0.01 \\
(0.01)\end{array}$ & $\begin{array}{c}0.00 \\
(0.02)\end{array}$ & $\begin{array}{r}-0.01 \\
(0.02)\end{array}$ & & & & \\
\hline $\begin{array}{l}\text { Ln community initiative } \\
\text { grants (ln HOBJ) }\end{array}$ & & $\begin{array}{l}0.03 * * * \\
(0.01)\end{array}$ & $\begin{array}{c}0.00 \\
(0.01)\end{array}$ & $\begin{array}{c}0.00 \\
(0.01)\end{array}$ & & & & \\
\hline $\begin{array}{l}\text { Ln French regional } \\
\text { policy (ln PAT) }\end{array}$ & & & & & & $\begin{array}{l}0.04 * * * \\
(0.01)\end{array}$ & $\begin{array}{c}0.02 \\
(0.02)\end{array}$ & $\begin{array}{c}0.02 \\
(0.02)\end{array}$ \\
\hline No. obs. & 1264 & 1264 & 1264 & 1264 & 1803 & 1803 & 1803 & 1803 \\
\hline Pseudo- $R^{2}$ & 0.193 & 0.166 & 0.172 & 0.194 & 0.192 & 0.17 & 0.173 & 0.192 \\
\hline
\end{tabular}

Note: standard errors in parentheses with significance at the $* * * 1 \%, * * 5 \%$ and $* 10 \%$ level. 
instance, which showed that firms are sensitive to tax and subsidy differentials in their location choice. Note also that this paper is not the first to find little or no effect of European structural funds on regional attractiveness and growth (see Boldrin and Canova, 2001; Ferrer, 1998; Martin, 1998). This does not necessarily mean that these policies are inefficient, but it casts doubt on the idea that the regional policy of the European Commission can actually influence or even reverse the 'natural' location patterns of economic activity in Europe.

There is a problem with the evaluation of the influence of these funds which is often mentioned to explain the apparent poor and even sometimes negative influence of these grants. Regional policies are designed to help lagging regions catch up or to compensate for a reduction in employment due to a structural crisis in the industries in which these regions specialize. The fact that a region is not successful at attracting FDI is often a cause of its economic problems and the consequence of this can be a negative coefficient on the grant variable observed by the researcher.

In order to address this potential problem and assess if an increase in the grants received by a region has a positive influence on location choice after having controlled for the structural characteristics of that region, we run fixed effects logits for structural funds and PAT in columns 3, 4 and 7, 8, respectively. Far from improving the estimated impact of those grants, the significantly positive coefficients become insignificant and Objective 2 funds are even found to have a significantly negative influence. The geographical level of the fixed effect does not change the results in any way whether or not we control for the constant characteristics of NUTS 3 or NUTS 2 regions.

We further evaluated the robustness of this apparent inefficiency of European grants on regional attractiveness by assessing the influence of past European regional policy on present location choices. Most structural funds are spent on transport, communication or other types of public infrastructure. Over time, the funds might have therefore improved the attractiveness of the region and investors in subsequent years might be less repelled by this region. ${ }^{17}$ We therefore estimate the impact of the overall funds received by French regions between 1989 and 1991 on the choices between 1992 and 1995 and compare the coefficients with the preceding regression. In order to save space, we do not include the results table here (they are available upon request), but the results are broadly similar. Only one coefficient is significantly positive and all estimates of the impact of regional European grants are of very low magnitude.

The pooled specifications therefore do not show any significant impact of regional policy measures that we were able to include in the analysis. However, some investors might be more sensitive than others to financial incentives in their location choice, leaving potential room for targeted policies. We now turn to an investigation of this possibility.

\subsection{Results by country of origin}

We concentrate here on assessing the impact of PAT because of the longer time period available and also because PAT is a more direct instrument for attracting FDI

\footnotetext{
17 Note that this argument does not hold for PAT, since this measure is direct aid to a firm investing in a lagging region.
} 
Table 5

Influence of regional policies on location choice by country

\begin{tabular}{|c|c|c|c|c|c|c|}
\hline Fixed effect & No & & NUTS 2 & & NUTS 3 & \\
\hline Ln proximity of other & $0.50 * * *$ & $(0.06)$ & $0.49 * * *$ & $(0.06)$ & $0.54 * * *$ & $(0.06)$ \\
\hline \multicolumn{7}{|l|}{ Ln proximity of } \\
\hline French firms (ln NF) & $1.11 * * *$ & $(0.04)$ & $1.14 * * *$ & $(0.04)$ & $1.17 * * *$ & $(0.04)$ \\
\hline \multicolumn{7}{|c|}{ Ln proximity of same home country firms (ln NH) } \\
\hline Belgium & 0.49 & $(0.41)$ & 0.59 & $(0.41)$ & 0.50 & $(0.42)$ \\
\hline Netherlands & $-2.35 * * *$ & $(0.49)$ & $-2.43 * * *$ & $(0.49)$ & $-2.07 * * *$ & $(0.51)$ \\
\hline Germany & -0.18 & $(0.23)$ & -0.26 & $(0.23)$ & -0.17 & $(0.22)$ \\
\hline Italy & 0.08 & $(0.47)$ & 0.12 & $(0.48)$ & 0.23 & $(0.49)$ \\
\hline UK & 0.10 & $(0.34)$ & 0.10 & $(0.35)$ & 0.22 & $(0.34)$ \\
\hline USA & 0.13 & $(0.15)$ & 0.15 & $(0.15)$ & 0.16 & $(0.15)$ \\
\hline Japan & 0.55 & $(1.15)$ & 0.57 & $(1.15)$ & 0.59 & (1.07) \\
\hline Switzerland & -0.25 & $(0.26)$ & -0.24 & $(0.26)$ & -0.38 & $(0.26)$ \\
\hline Other countries & $1.41 * *$ & $(0.56)$ & $1.30 * *$ & $(0.56)$ & $1.13 * *$ & $(0.56)$ \\
\hline
\end{tabular}

Ln market

potential (ln MARK)

By country-not reported

Ln wage $(\ln W)$

\begin{tabular}{|c|c|c|c|c|c|c|}
\hline Belgium & $-1.40 * * *$ & $(0.44)$ & $-1.45 * * *$ & $(0.43)$ & $-1.47 * * *$ & $(0.44)$ \\
\hline Netherlands & 0.46 & $(0.59)$ & 0.37 & $(0.59)$ & 0.28 & $(0.59)$ \\
\hline Germany & 0.07 & $(0.36)$ & -0.02 & $(0.36)$ & 0.06 & $(0.36)$ \\
\hline Italy & $-1.16^{* * *}$ & $(0.34)$ & $-1.32 * * *$ & $(0.35)$ & $-1.09 * * *$ & $(0.36)$ \\
\hline UK & -0.36 & $(0.51)$ & -0.41 & $(0.51)$ & -0.38 & $(0.51)$ \\
\hline USA & $0.83 * * *$ & $(0.27)$ & $0.80 * * *$ & $(0.27)$ & $0.78 * * *$ & $(0.28)$ \\
\hline Japan & 0.81 & $(0.94)$ & 0.79 & $(0.95)$ & 0.64 & $(0.94)$ \\
\hline Switzerland & 0.35 & $(0.48)$ & 0.38 & $(0.48)$ & 0.51 & $(0.48)$ \\
\hline Other countries & 0.81 & $(0.50)$ & 0.80 & $(0.50)$ & $0.89 *$ & $(0.50)$ \\
\hline \multicolumn{7}{|c|}{ Ln French regional policy (In PAT) } \\
\hline Belgium & $0.07 * *$ & $(0.03)$ & 0.04 & $(0.03)$ & 0.04 & $(0.03)$ \\
\hline Netherlands & 0.03 & $(0.03)$ & 0.00 & $(0.03)$ & 0.01 & $(0.03)$ \\
\hline Germany & $0.08 * * *$ & $(0.02)$ & $0.05 *$ & $(0.03)$ & $0.05 * *$ & $(0.03)$ \\
\hline Italy & $0.15 * * *$ & $(0.02)$ & $0.11 * * *$ & $(0.03)$ & $0.08 * * *$ & $(0.03)$ \\
\hline UK & 0.01 & $(0.02)$ & -0.02 & $(0.03)$ & -0.01 & $(0.03)$ \\
\hline USA & 0.01 & $(0.01)$ & -0.03 & $(0.02)$ & -0.03 & $(0.02)$ \\
\hline Japan & 0.04 & $(0.05)$ & 0.00 & $(0.05)$ & 0.01 & $(0.05)$ \\
\hline Switzerland & 0.01 & $(0.02)$ & -0.03 & $(0.03)$ & -0.03 & $(0.03)$ \\
\hline Other countries & $0.07 * * *$ & $(0.02)$ & 0.03 & $(0.03)$ & 0.03 & $(0.03)$ \\
\hline \multicolumn{5}{|l|}{ Ln distance to home } & $-0.59 * * *$ & $(0.10)$ \\
\hline No. obs. & 1803 & & 1803 & & 1803 & \\
\hline Pseudo- $R^{2}$ & 0.185 & & 0.188 & & 0.204 & \\
\hline
\end{tabular}

Note: standard errors in parentheses with significance at the $* * * 1 \%, * * 5 \%$ and $* 10 \%$ level. 
than structural funds. One can explain the extremely small consequences of European grants on FDI flows by arguing that they have as an objective to promote regional development and attractiveness, but not to directly affect location choices. On the contrary, PAT is explicitly a direct regional policy in favor of foreign investments. However, we see from Table 5 that the impact of French regional policy (at least its observable part measured as PAT funds) is far from being as influential on location choices as the policy makers would like it to be, even when investigating different origin countries in detail.

This table reproduces the estimations of Table 2 for the sample of years where PAT data are available and adding interacted variables between PAT grants and origin country dummies. The only three countries for which we find a positive impact are Belgium, Germany and Italy in the first regression, and the impact for Belgium loses significance with NUTS 3 fixed effects. Even for those countries, the effect of grants on location choice is relatively marginal in magnitude when compared to other determinants.

The Italian case is very interesting as it appears that investors from this country are very sensitive to monetary incentives compared to other investors. Indeed, the positive effect of grants is highly significant and the largest of all countries. Furthermore, Italian firms also prove to be among the most highly sensitive to wage differentials and show little tendency to agglomerate relative to other countries.

Our study therefore leaves very little prospect for an efficient regional policy. Indeed, the investors that are sensitive to these measures are only slightly so and do not cluster much, hence the benefits of grants to the region are likely to be very small. Success in attracting initial investments from these countries is not sufficient to generate a self-reinforcing agglomeration of firms from those countries.

\section{Conclusion}

We assess in this paper the determinants of location choice of foreign investors in France. We focus in particular on the existence and magnitude of agglomeration economies and identify the countries of origin and industries for which positive spillovers suggested by the observed clustering between firms are more pronounced. It appears that computers, car parts, machine tools and office machinery are examples of sectors characterized by the strongest agglomeration effects. A $10 \%$ increase in the number of competitors in a location can increase by up to $40 \%$ the average probability of investing in that location. On the other hand, firms originating from countries such as Italy or the Netherlands and from industries such as clothing are much less subject to clustering and more sensitive to the level of wages in their location patterns.

We also uncovered general patterns of FDI location that, to our knowledge, have not been the subject of rigorous empirical investigation. Among these, the location behavior of foreign firms in France seems to suggest that a learning process takes place in location choice over time. Firms tend to choose locations in France that are near their home market 
throughout the whole period, particularly when the investor is from Germany, Belgium, Switzerland or the Netherlands. However, this pattern gradually fades over the period studied as the impact of market potential becomes larger and clustering behavior becomes weaker. We interpret this evolution as evidence of learning about French market characteristics by foreign firms. As time passes it becomes more and more important to be near the final demand and less and less important to be in locations sharing common attributes with the home country.

Finally, we attempted to assess the impact of French and European regional policies through the inclusion of investment incentives and structural funds in the location choice, but found hardly any positive impact of either measure on the actual choices of investors. Even if important agglomeration economies might be favorable grounds for effective attractiveness and regional policies, the evidence for France is very negative. We do not find any increase in the attractiveness of French départements when investing there is associated with grants from public authorities.

\section{Acknowledgements}

This research benefited from the financial assistance of L'Istituto Affari Internazionali (Rome) and the Commissariat Général du Plan (Paris, convention 4-98). The authors gratefully acknowledge the help of Séverine Chédor in processing data for us at the French Ministry of Industry. The authors are grateful to two anonymous referees whose comments proved very useful in clarifying and improving the paper. Françoise Maurel also provided very helpful comments, as did several participants at seminars at the University of Kiel, Paris 9 and Paris 10, and Séminaire Fourgeaud at the French Ministry of Finance.

\section{Appendix A. Location choice determinants by industry}

Table A.1

Most agglomerated industries

\begin{tabular}{lclllrrr}
\hline Industry & No. obs. & NH & NO & NF & MARK & W & DIS \\
\hline Office machinery & 9 & $3.98^{* *}$ & $3.63^{*}$ & $5.44^{* * *}$ & $-2.00^{* *}$ & 0.81 & -1.85 \\
Lightning & 19 & $2.38^{* *}$ & $2.26^{* * *}$ & $2.22^{* * *}$ & $-1.44^{* * *}$ & 0.71 & $-1.46^{*}$ \\
Machine tools & 23 & $1.67^{*}$ & $1.53^{* * *}$ & $1.43^{* * *}$ & $0.70^{* *}$ & -0.67 & $-1.21^{* *}$ \\
Misc. rubber & 36 & $1.98^{* * *}$ & $1.12^{* * *}$ & $1.47^{* * *}$ & 0.36 & -0.97 & -0.90 \\
Lifts & 85 & $1.41^{* *}$ & $0.47^{*}$ & $1.67^{* * *}$ & -0.34 & $-1.08^{*}$ & -0.02 \\
Computers & 71 & $1.07^{* * *}$ & $0.99^{* * *}$ & $1.47 * * *$ & $-0.51^{*}$ & $1.11 * *$ & 0.67 \\
Paints & 65 & $0.93^{* *}$ & $0.92^{* * *}$ & $1.48^{* * *}$ & -0.22 & -0.63 & 0.03 \\
Car parts & 115 & $0.59^{* * *}$ & $0.35^{*}$ & $1.08^{* * *}$ & 0.10 & 0.41 & $-0.72^{*}$ \\
\hline
\end{tabular}

Note: $* * *, * *$ and $*$ respectively denote significance at the $1 \%, 5 \%$ and $10 \%$ level. 
Table A.2

Location patterns of other industries

\begin{tabular}{|c|c|c|c|c|c|c|c|}
\hline Industry & No. obs. & $\mathrm{NH}$ & $\mathrm{NO}$ & $\mathrm{NF}$ & MARK & $\mathrm{W}$ & DIS \\
\hline Springs & 11 & $3.57 * *$ & 0.72 & $3.96 * * *$ & -0.11 & $-4.08 * *$ & 0.96 \\
\hline Plaster for construction & 7 & $4.2 * *$ & 0.99 & $2.74 * * *$ & -0.37 & 1.24 & -0.95 \\
\hline Jewellery & 30 & $5.37 * * *$ & 0.14 & $1.22 * * *$ & $0.63 *$ & $-3.23 * * *$ & -0.85 \\
\hline Transmission parts & 17 & 2.83 & $2.16 * * *$ & $1.72 * * *$ & 0.12 & 2.79 & 0.07 \\
\hline Paste and glue & 21 & 1.33 & $1.78 * * *$ & $3.53 * * *$ & $-0.95 * *$ & $2.57 *$ & $-1.48 * *$ \\
\hline Soap & 17 & $2.25 * *$ & 0.47 & $2.63 * * *$ & -0.59 & 2.1 & $-1.69 *$ \\
\hline Basic plastics & 17 & $2.31 * * *$ & 0.54 & $2.49 * * *$ & 0.91 & 0.2 & $-2.92 * * *$ \\
\hline Cardboards & 11 & $2.43 *$ & 0.71 & $2.16 * * *$ & -0.42 & 1.38 & -0.75 \\
\hline Screws & 7 & 2.33 & 1.33 & $1.46^{* *}$ & 0.72 & -0.42 & $-2.7^{*}$ \\
\hline Small metal articles & 10 & 1.33 & $2.02 *$ & $1.68^{*}$ & -0.15 & -0.02 & $-3.77 * * *$ \\
\hline Industrial gas & 50 & $2.26 * *$ & 0.5 & $2.22 * * *$ & -0.61 & -1.08 & 0.46 \\
\hline Curved glass & 8 & $4.35^{*}$ & -2.42 & $2.92 * * *$ & $-1.99 * *$ & $-5.54 * *$ & $-3.8 * *$ \\
\hline Small gen., eng. and transf. & 9 & 0.06 & 1.66 & $2.68 * * *$ & $-2.06 * *$ & 2.35 & $-3.3 * *$ \\
\hline Agricultural machinery & 11 & 2.07 & 0.43 & $1.73 * * *$ & 0.99 & -0.86 & 1.29 \\
\hline Cables and wires & 20 & $2 * *$ & 0.67 & $1.49 * * *$ & 0.01 & -1.55 & -0.17 \\
\hline Car bodies & 21 & 1.34 & $1.15^{*}$ & $1.29 * * *$ & 0.45 & 0.95 & -0.18 \\
\hline Navigation equipment & 26 & 1.49 & $1.27 * *$ & $0.95 * *$ & -0.34 & -0.7 & $-1.19 *$ \\
\hline Dom. elec. appliances & 13 & -0.17 & $1.8 * *$ & $1.84 * * *$ & -0.82 & $3.4 * * *$ & -0.16 \\
\hline Mechanical handling eq. & 27 & 0.94 & $1.12 * * *$ & $1.18 * * *$ & 0.35 & -0.21 & -0.49 \\
\hline Active electronic comp. & 21 & -0.04 & $1.21 * *$ & $2.02 * * *$ & $0.77 *$ & 0.05 & 1.11 \\
\hline Tabs & 27 & 1.24 & 0.46 & $1.1 * * *$ & -0.04 & 1.83 & 0.03 \\
\hline Misc elec. mat. & 12 & 1.31 & 0.67 & 0.64 & 0.66 & 1.42 & 0.44 \\
\hline Locks & 19 & 1.01 & 0.27 & $1.3 * * *$ & $0.69 *$ & -1.6 & -1 \\
\hline Essential oils & 26 & 0.03 & $1.08 * *$ & $1.41 * * *$ & $1.24 * * *$ & -1.13 & 0.26 \\
\hline Men's apparel & 10 & 0.91 & -0.46 & $2.05 * * *$ & -0.19 & $-3.37 *$ & $-1.86^{* *}$ \\
\hline Metal treatment & 29 & -0.06 & $1.29 * * *$ & $1.24 * * *$ & 0 & -1.05 & $-1.26^{* *}$ \\
\hline Mechanical tools & 51 & 0.95 & $0.87 * * *$ & $0.64 * *$ & 0.13 & -0.33 & -0.16 \\
\hline Shoes & 19 & 1.23 & 0.46 & $0.65 * * *$ & $1.36 * * *$ & -1.44 & -1.09 \\
\hline Concrete for cons. & 29 & 0.27 & $0.7 *$ & $1.36 * * *$ & 0.53 & -0.01 & $-1.42 * * *$ \\
\hline Food ind. machinery & 51 & 0.66 & 0.01 & $1.65 * * *$ & 0.25 & 0.7 & $-1.31 * *$ \\
\hline Batteries & 22 & -0.94 & 0.93 & $2.26 * * *$ & -0.13 & 0.69 & -1.24 \\
\hline Perfume & 49 & 0.42 & -0.59 & $2.41 * * *$ & -0.35 & 0.29 & -0.92 \\
\hline Tech. plastic parts & 45 & 0.85 & 0.25 & $1.08 * * *$ & 0.11 & 0.23 & $-1.06^{* *}$ \\
\hline Industrial chemicals & 47 & -0.07 & $0.96 * * *$ & $1.3 * * *$ & -0.1 & $2.2 * *$ & -0.78 \\
\hline Construction machinery & 31 & $1.36^{*}$ & -0.53 & $1.22 * * *$ & 0.5 & 0.22 & -0.69 \\
\hline Office furniture & 20 & $2.37 * *$ & -0.73 & 0.33 & $1.25 * *$ & -1.21 & -0.92 \\
\hline Transmission equipment & 20 & 0.13 & 0.04 & $1.77 * * *$ & 0.27 & 1.17 & $4.55 * * *$ \\
\hline Clothing accessories & 28 & 0.3 & 0.07 & $1.56 * * *$ & -0.72 & 1.82 & $-2.24 * * *$ \\
\hline Light metal packaging & 14 & 0.2 & -0.38 & $2.09 * * *$ & $1.06 * *$ & -2.17 & -0.62 \\
\hline Glasses & 12 & -0.13 & 0.57 & $1.43 * * *$ & 0.27 & 3.23 & -0.6 \\
\hline Low tension elec. eq. & 68 & 0.41 & $0.73 * *$ & $0.73 * * *$ & $0.49 *$ & -1.27 & -0.16 \\
\hline Pharmaceuticals & 126 & 0.21 & $0.49 * *$ & $1.12 * * *$ & 0.09 & 0.03 & -0.46 \\
\hline Cement & 15 & -0.35 & 0.85 & $1.27 * *$ & -0.21 & 1.32 & $-1.96 * * *$ \\
\hline Plastic for packaging & 42 & 0.82 & 0.09 & $0.76^{* * *}$ & $0.73 * * *$ & -0.86 & -0.75 \\
\hline Misc. organic chemicals & 19 & -0.14 & 0.45 & $1.27 * * *$ & $0.76^{*}$ & -0.4 & $-1.19 *$ \\
\hline Pumps and compressors & 49 & -0.89 & $1.09 * * *$ & $1.34 * * *$ & -0.1 & $2.95 * * *$ & 0.63 \\
\hline Telephones & 32 & -0.48 & 0.63 & $1.4^{* *}$ & -0.32 & 1.55 & -0.23 \\
\hline Scientific inst. & 117 & -0.09 & 0.28 & $1.22 * * *$ & -0.13 & 0.99 & $-0.85^{* *}$ \\
\hline Ind. refrigerating mach. & 71 & -0.49 & $0.49 * *$ & $1.4 * * *$ & -0.4 & 0.69 & -0.46 \\
\hline Agri. use chem. & 37 & -2.02 & $1.01 * *$ & $2.27 * * *$ & -0.5 & $2.05 * * *$ & $1.86^{* *}$ \\
\hline
\end{tabular}


Table A.2 (continued)

\begin{tabular}{|c|c|c|c|c|c|c|c|}
\hline Industry & No. obs. & $\mathrm{NH}$ & NO & NF & MARK & W & DIS \\
\hline Springs & 11 & $3.57 * *$ & 0.72 & $3.96^{* * *}$ & -0.11 & $-4.08 * *$ & 0.96 \\
\hline Wood structure & 8 & 1.36 & -0.05 & -0.07 & $1.88 * * *$ & -2.8 & $-3.55^{* * *}$ \\
\hline Book publishing & 321 & $0.57 * *$ & $0.54 * * *$ & 0.05 & $0.84 * * *$ & $-1.3 * * *$ & -0.37 \\
\hline Plastic tubes & 46 & -0.41 & -0.11 & $1.47 * * *$ & $0.47 *$ & -0.64 & -0.6 \\
\hline Boilermaking & 30 & 0.1 & 0.38 & 0.37 & 0.59 & 2.11 & $-1.12^{* *}$ \\
\hline Oil refining & 184 & -0.51 & -0.01 & $1.23 * * *$ & $0.5 * * *$ & -0.33 & 0.25 \\
\hline Hydraulic transmissions & 40 & -0.87 & -0.19 & $1.78 * * *$ & 0.27 & -0.86 & -0.32 \\
\hline Plastics for construction & 60 & $-0.76^{*}$ & 0.1 & $1.31 * * *$ & $0.65 * * *$ & $-1.36^{*}$ & $-1.72 * * *$ \\
\hline Clocks & 13 & $-1.92 * *$ & 0.14 & $2.38 * * *$ & 0.99 & 0.94 & $-2.74 * *$ \\
\hline Passive electronic comp. & 43 & -0.68 & -0.14 & $1.42 * * *$ & 0.42 & 1.06 & -1.49 \\
\hline \multicolumn{8}{|l|}{ Other paper and } \\
\hline cardboard art. & 35 & -1.69 & $0.8 * *$ & $1.39 * * *$ & -0.17 & -0.81 & -0.68 \\
\hline Printing & 37 & -0.38 & -0.31 & $1.12 *$ & 0.43 & 0.51 & $-1.71 * * *$ \\
\hline Women's apparel & 251 & 0.34 & -0.26 & $0.24 * *$ & $1.22 * * *$ & $-1.02 * * *$ & -0.06 \\
\hline Paper and cardboard & 17 & -0.53 & -1.1 & $1.68 * * *$ & -0.4 & $2.79 * *$ & $-1.85^{*}$ \\
\hline Misc. machinery & 25 & 1.45 & -2.78 & $0.99 * *$ & 0.54 & -0.88 & 0.14 \\
\hline General machinery & 28 & -1.14 & 0.2 & 0.51 & $1.27 * *$ & -1.99 & $-1.67 * * *$ \\
\hline Silk manufacturing & 13 & -2.32 & 0.42 & $0.92 *$ & $1.2 * * *$ & $-2.75^{* *}$ & 0.51 \\
\hline Newspaper publishing & 25 & 0.26 & -0.3 & -1.39 & $5.77 * * *$ & 2.84 & -0.08 \\
\hline Underwear & 8 & 0.46 & -2.23 & -0.25 & $3.37 * * *$ & $-3.95^{*}$ & -1.41 \\
\hline Magazine publishing & 27 & -1.3 & 0.31 & -1.04 & 4.39 & $5.86^{* *}$ & -1.45 \\
\hline
\end{tabular}

Note: $* * *, * *$ and $*$ respectively denote significance at the $1 \%, 5 \%$ and $10 \%$ level.

\section{References}

Arthur, W.B., 1990. Silicon valley locational clusters: when do increasing returns imply monopoly? Mathematical Social Science 19 (3), 235-251.

Arthur, W.B., 1994. Increasing Returns and Path Dependence in the Economy. University of Michigan Press.

Banerjee, A., 1992. A simple model of herd behaviour. Quarterly Journal of Economics 57, 797-817.

Belleflamme, P., Picard, P., Thisse, J.-F., 2000. An economic theory of regional clusters. Journal of Urban Economics 48 (1), 158-184.

Boldrin, M., Canova, F., 2001. Inequality and convergence in Europe's regions: reconsidering European regional policies. Economic Policy 32, 205-253.

Carlton, D., 1983. The location and employment choices of new firms: an econometric model with discrete and continuous endogenous variables. Review of Economics and Statistics 65, 440-449.

David, P.A., Rosenbloom, J.L., 1990. Marshallian factor market externalities and the dynamics of industrial localisation. Journal of Urban Economics 28 (3), 349-370.

d'Aspremont, C., Gabszewicz, J.J., Thisse, J.F., 1979. On Hotelling's stability in competition. Econometrica 47, $1045-1050$.

De Coster, G., Strange, W., 1993. Spurious agglomeration. Journal of Urban Economics 33, $273-304$.

Devereux, M., Griffith, R., 1998. Taxes and the location of production: evidence from a panel of US multinationals. Journal of Public Economics 68 (3), 335-367.

Ferrer, C., 1998. Patterns and determinants of location decisions by French multinationals in European regions. In: Mucchielli, J.-L. (Ed.), Multinational Location Strategy. JAI Press, Greenwich.

Friedman, J., Gerlowski, D., Silberman, J., 1992. What attracts foreign multinational corporations. Journal of Regional Science 32 (4), $403-418$.

Fujita, M., Thisse, J.F., 1996. Economics of agglomeration. Journal of the Japanese and International Economies $10(4), 339-378$.

Fujita, M., Thisse, J.F., 2002. Economics of Agglomeration. Cambridge University Press, Cambridge. 
Guimarães, P., Figueiredo, O., Woodward, D., 2000. Agglomeration and the location of foreign direct investment in Portugal. Journal of Urban Economics 47 (1), 115-135.

Hansen, E.R., 1987. Industrial location choice in Sao Paulo, Brazil, a nested logit model. Regional Science and Urban Economics 17 (1), 89-108.

Hanson, G., 1998. Market potential, increasing returns, and geographic concentration. National Bureau of Economic Research Working Paper \# 6429.

Harris, C., 1954. The market as a factor in the localization of industry in the United States. Annals of the Association of American Geographers 64, 315-348.

Head, K., Ries, J., 1996. Inter-city competition for foreign investment: static and dynamic effects of China's incentive areas. Journal of Urban Economics 40 (1), 38-60.

Head, K., Ries, J., Swenson, D., 1995. Agglomeration benefits and location choice: evidence from Japanese manufacturing investment in the United States. Journal of International Economics 38 (3/4), $223-247$.

Head, K., Ries, J., Swenson, D., 1999. Attracting foreign manufacturing: investment promotion and agglomeration. Regional Science and Urban Economics 29 (2), 197-218.

Henderson, J.V., Kuncoro, A., 1996. Industrial centralisation in Indonesia. World Bank Economic Review 10 (3), $513-540$.

Hirsch, S., 1976. An international trade and investment theory of the firm. Oxford Economic Papers 28 (2), 258-270.

Krugman, P.R., 1991. Geography and Trade. MIT Press, Cambridge.

Maddala, G.S., 1983. Limited-dependent and Qualitative Variables in Econometrics. Cambridge University Press, Cambridge.

Marshall, A., 1920. Principles of Economics. Macmillan, London.

Martin, P., 1998. Can regional policies affect growth and geography in Europe. World Economy 21 (6), $757-774$.

Mayer, T., Mucchielli, J.L., 1999. La localisation à l'étranger des entreprises multinationales: une approche d'économie géographique hiérarchisée appliquée aux entreprises japonaises en Europe. Économie et Statistique 326/327, 159-167.

McFadden, D., 1984. Econometric analysis of qualitative response models. In: Griliches, Z., Intriligator, M.D. (Eds.), Handbook of Econometrics, Vol. 2. Elsevier/North-Holland, Amsterdam.

Rauch, J.E., 1999. Networks versus markets in international trade. Journal of International Economics 48 (1), $7-35$.

Rauch, J.E., 2001. Business and social networks in international trade. Journal of Economic Literature 39 (4), $1177-1203$.

Rose, A., 2000. One money, one market: the effect of common currencies on trade. Economic Policy 30, 9-33.

Venables, A.J., 1996. Equilibrium locations of vertically linked industries. International Economic Review 37 (2), $341-359$.

Wheeler, D., Mody, A., 1992. International investment location decisions. Journal of International Economics 33, 57-76. 